\title{
Cell proliferation in Helicobacter pylori associated gastritis and the effect of eradication therapy
}

\author{
D A F Lynch, N P Mapstone, A M T Clarke, G M Sobala, P Jackson, L Morrison, \\ M F Dixon, P Quirke, A T R Axon
}

\begin{abstract}
Helicobacter pylori causes chronic (type B) gastritis. The 'intestinal' form of gastric cancer arises against a background of chronic gastritis, and prospective epidemiological studies have shown that $H$ pylori is a major risk factor for this. An increase in mucosal cell proliferation increases the likelihood of a neoplastic clone of epithelial cells emerging where there is chronic epithelial cell injury associated with $H$ pylori gastritis. In vitro bromodeoxyuridine labelling of endoscopic antral biopsy specimens was used to measure mucosal cell proliferation in $H$ pylori associated gastritis before and after therapy for $H$ pylori triple infection. Cell proliferation was increased in $H$ pylori associated gastritis patients compared with normal controls and patients with $H$ pylori negative chronic gastritis $(p=0.0001$; Tukey's Studentised range). There was no difference in antral epithelial cell proliferation between duodenal ulcer and non-ulcer subjects infected with $H$ pylori ( $p=0.62$; Student's $t$ test). Antral mucosal cell proliferation fell four weeks after completing triple therapy, irrespective of whether or not $H$ pylori had been eradicated $(p=0 \cdot 0001)$. At retesting six to 18 months later (mean=12 months), however, those in whom $H$ pylori had not been successfully eradicated showed increased mucosal proliferation compared with both $H$ pylori negative subjects at a similar follow up interval and all cases (whether $H$ pylori positive or negative) four weeks after completion of triple therapy $(p=0.024)$. These findings suggest that $\boldsymbol{H}$ pylori infection causes increased gastric cell proliferation and in this way may play a part in gastric carcinogenesis.

(Gut 1995; 36: 346-350)
\end{abstract}

Keywords: Helicobacter pylori, type B gastritis, gastric cancer, cell proliferation.

Accepted for publication 15 July 1994

TABLE I Antral mucosal cell proliferation in Helicobacter pylori associated gastritis

\begin{tabular}{|c|c|c|c|}
\hline & \multicolumn{3}{|l|}{ Group } \\
\hline & Controls $(n=12)$ & H pylori $-v e(n=10)$ & $\mathrm{H}$ pylori $+v e(n=42)$ \\
\hline $\begin{array}{l}\text { Mean (SEM) age (y) } \\
\text { Mean (SEM) LI\%: }\end{array}$ & $42.3(3.51)$ & $34 \cdot 4(3 \cdot 35)$ & $43.8(2 \cdot 49)$ \\
\hline $\begin{array}{l}\text { Zone } 1 \\
\text { Zone } 2 \\
\text { Zone } 3 \\
\text { Total LI\% }\end{array}$ & $\begin{array}{c}0.7(0.15) \\
11.5(1.22) \\
0.4(0.15) \\
4.35(0.51)\end{array}$ & $\begin{array}{r}1.0(0.37) \\
10.3(1.82) \\
0.2(0.09) \\
3.7(0.65)\end{array}$ & $\begin{array}{c}1.3(0.15) \\
17.9(1.14)^{\star} \\
1.0(0.16) \\
6.8(0.28)^{\star}\end{array}$ \\
\hline
\end{tabular}

$\mathrm{LI}=$ labelling index. One way analysis of variance indicates that both total antral gastric gland $\mathrm{LI} \%$ and zone $2 \mathrm{LI} \%$ are increased in $H$ pylori associated gastritis ( + ve) compared with $H$ pylori negative chronic gastritis ( $-v e)$ and normal control subjects $(p=0.0001$; Tukey's studentised range). ${ }^{\star}$ Indicates that group is significantly different from the others.
The 'intestinal' form of gastric cancer, which is the commonest type, develops against a background of chronic gastritis, atrophy, and intestinal metaplasia. ${ }^{12}$ Helicobacter pylori is the cause of (type B) chronic gastritis and has been shown in epidemiological studies to be a major risk factor for the development of gastric cancer. ${ }^{3-6}$ Increased mucosal cell proliferation increases the likelihood of the development of a neoplastic clone of epithelial cells ${ }^{7}$ where there is chronic epithelial injury associated with $H$ pylori positive gastritis. However, little is known about cell proliferation in $H$ pylori associated gastritis.

The aims of the study were, firstly, to compare antral mucosal cell proliferation in normal gastric mucosa with $H$ pylori positive and negative chronic gastritis and, secondly, to determine the effect of $H$ pylori eradication treatment on cell proliferation.

\section{Methods}

Patients undergoing routine diagnostic endoscopy were recruited after informed consent. Those taking non-steroidal anti-inflammatory drugs, $\mathrm{H}_{2}$ antagonists, proton pump inhibitors, or bismuth salts, or those who had undergone gastric surgery, were excluded from the study. Using standard biopsy forceps, tissue specimens were taken from the gastric antrum (three) and corpus (two) for histological and immunohistochemical studies. The study was approved by the hospital ethical committee.

\section{HISTOLOGY}

Two antral and two corpus biopsy specimens from each site were routinely processed, and stained with haematoxylin and eosin.

H PYLORI

$H$ pylori status was determined using a modified Giemsa stain on the antral and corpus sections and a biopsy urease test (CLO/DeltaWest) on the third antral biopsy specimen. To establish eradication of the micro-organism, both tests had to be negative.

\section{IMMUNOHISTOCHEMISTRY}

Two antral biopsy specimens for immunostaining were put immediately into RPMI (without L-Glutamine) (Gibco) containing bromodeoxyuridine $(5 \mathrm{mg} / 10 \mathrm{ml})$. They were immersed in a waterbath for 60 minutes at $37^{\circ} \mathrm{C}$ then placed on filter paper and fixed in 


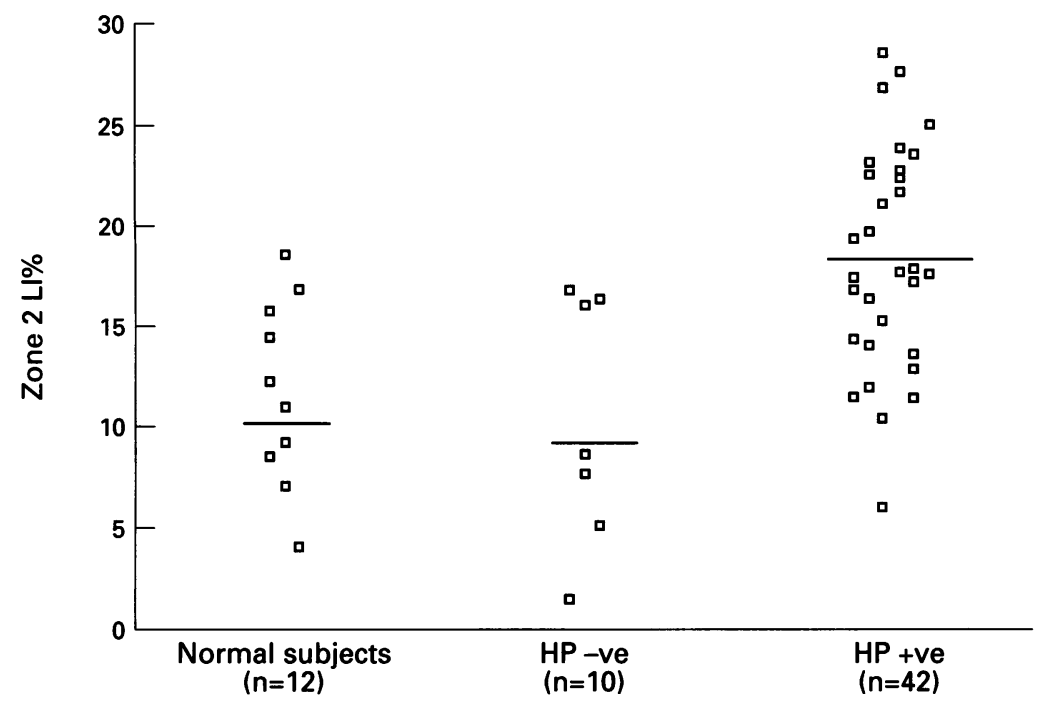

Figure 1: Antral zone 2 labelling index (LI\%) is increased in Helicobacter pylori chronic gastritis $(H P+v e)$ compared with normal gastric mucosa and $\mathrm{H}$ pylori negative chronic gastritis $(H P-v e)(p=0.0001)$.
TABLE II Antral mucosal cell proliferation in ulcer and non-ulcer associated Helicobacter pylori gastritis

\begin{tabular}{llr}
\hline & \multicolumn{1}{l}{ Group } \\
\cline { 2 - 3 } & $\begin{array}{l}\text { Non-ulcer gastritis } \\
(n=23)\end{array}$ & $\begin{array}{l}\text { Ulcer gastritis } \\
(n=19)\end{array}$ \\
\hline Mean (SEM) age (y) & $45 \cdot 6(2 \cdot 3)$ & $41.9(2 \cdot 68)$ \\
Mean (SEM) LI\%: & $1 \cdot 1(0 \cdot 23)$ & $1.5(0 \cdot 19)$ \\
Zone 1 & $17.6(1 \cdot 17)$ & $18 \cdot 3(1 \cdot 10)$ \\
Zone 2 & $0.6(0 \cdot 11)$ & $1.5(0 \cdot 29)$ \\
Zone 3 & $6.7(0.37)$ & $6.8(0.28)$ \\
Total LI\% & & \\
\hline
\end{tabular}

$\mathrm{LI}=$ labelling index. No difference in total antral $\mathrm{LI} \%$ and zone $2 \mathrm{LI} \%$ was observed between duodenal ulcer and non-ulcer associated $H$ pylori gastritis ( $\mathrm{p}=0.62$; Student's $t$ test).

present) was counted in each zone and expressed as a percentage. This value corresponds to the labelling index (LI\%). The total $\mathrm{LI} \%$ for the gastric glands was calculated from the sum of zones $1-3$. Only unequivocally stained cells were counted as positive. All sections were counted by one person who was unaware of the subject's $H$ pylori status.

formalin. Using a three step immunoperoxidase technique, sections were stained with anti-bromodeoxyuridine (DAKOPATT) antibody (1:20 dilution) for 60 minutes. Only sections that were complete and orientated were counted. For the purpose of counting, the gastric mucosa was divided into three zones: zone 1 =surface and gastric pit; zone $2=$ isthmus; zone $3=$ glandular layer. The number of cells to be counted in each zone was determined by counting consecutive high power fields until the continuous mean varied by less than $5 \%$. Five hundred cells were found to be necessary. The number of positively staining nuclei per 500 epithelial cell nuclei (or whole section when less than 500 cells per zone were

\section{ERADICATION THERAPY}

Anti-helicobacter therapy consisted of a two week course of tetracycline $500 \mathrm{mg}$ four times daily, metronidazole $400 \mathrm{mg}$ three times daily, and tripotassium dicitrato-bismuthate $120 \mathrm{mg}$ four times daily.

\section{STATISTICAL ANALYSIS}

Tukey's studentised range was used for three way analysis of data where appropriate. Student's $t$ test was used for comparison of parametric data and Wilcoxon signed rank test for analysis of paired data. A p value of less than 0.05 was regarded as significant.
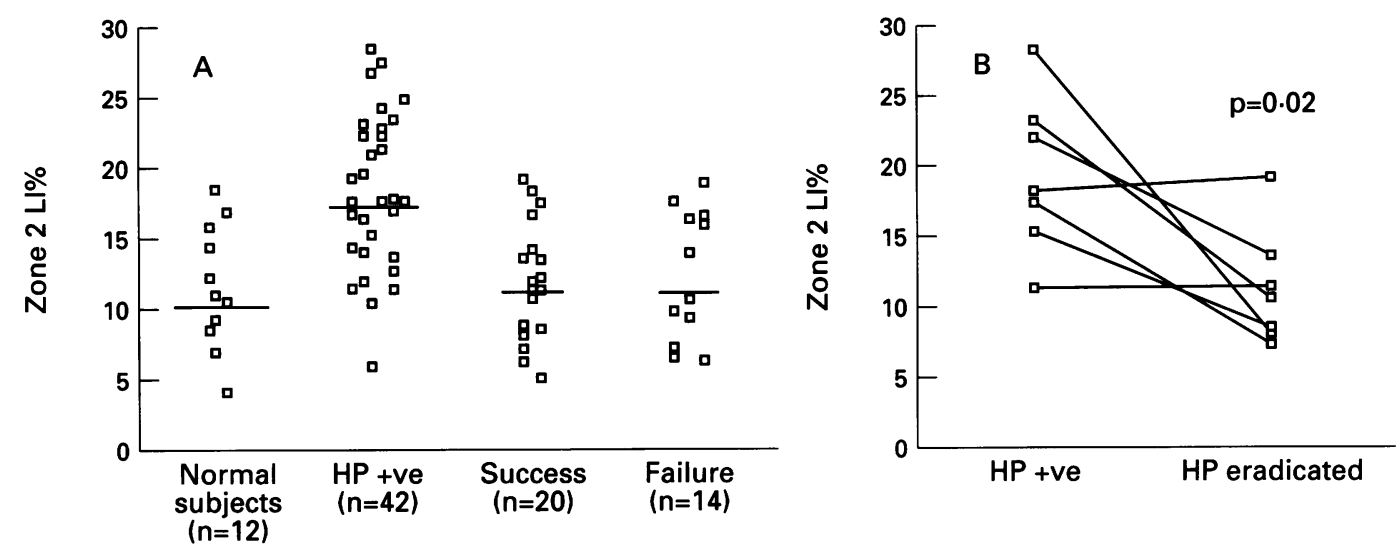

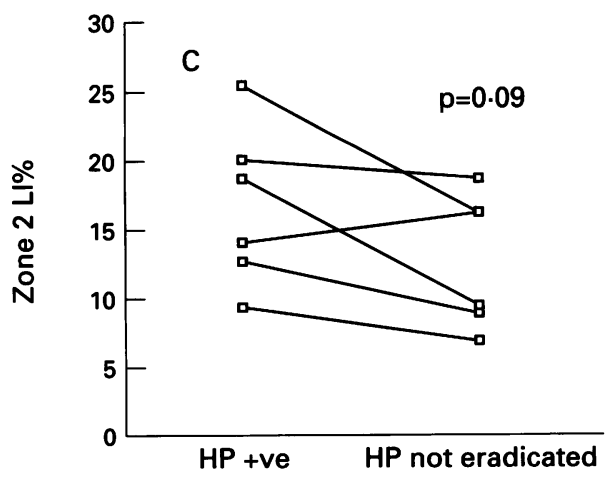

Figure 2: $(A),(B)$, and (C) Results at four weeks. The antral zone labelling index (LI\%) is reduced in subjects four weeks after eradication therapy whether or not $\mathrm{H}$ pylori has been eradicated. 
TABLE III Effect of treatment four weeks after completion on Helicobacter pylori positive patients

\begin{tabular}{|c|c|c|c|}
\hline & \multicolumn{3}{|l|}{ Group } \\
\hline & $\underset{(n=42)}{\mathrm{H} \text { pylori }}+v e$ & $\begin{array}{l}\text { H pylori eradicated } \\
(n=20)\end{array}$ & $\begin{array}{l}\mathrm{H} \text { pylori not eradicated } \\
(n=14)\end{array}$ \\
\hline $\begin{array}{l}\text { Mean (SEM) age (y) } \\
\text { Mean (SEM) LI\% }\end{array}$ & $43 \cdot 8(2 \cdot 49)$ & $45 \cdot 2(2 \cdot 65)$ & $46 \cdot 1(3.02)$ \\
\hline $\begin{array}{l}\text { Zone } 1 \\
\text { Zone } 2 \\
\text { Zone } 3 \\
\text { Total LI\% }\end{array}$ & $\begin{array}{c}1.3(0.15) \\
17.9(1.14)^{\star} \\
1.0(0.16) \\
6.8(0.28)^{\star}\end{array}$ & $\begin{array}{c}0.9(0.21) \\
12.0(0.96) \\
0.8(0.2) \\
4.5(0.30)\end{array}$ & $\begin{array}{c}1.4(0 \cdot 3) \\
11.8(1 \cdot 22) \\
1.0(0 \cdot 26) \\
4.9(0 \cdot 46)\end{array}$ \\
\hline
\end{tabular}

$\mathrm{LI}=$ labelling index. Total antral $\mathrm{LI} \%$ and zone $2 \mathrm{LI} \%$ are reduced in subjects four weeks after completing anti-helicobacter triple therapy whether $H$ pylor $i$ has been eradicated or not $(p=0.0001)$.
TABLE IV Short term (four weeks) effect of anti-helicobacter therapy on antral cell proliferation

\begin{tabular}{|c|c|c|c|c|}
\hline \multirow{3}{*}{$\begin{array}{l}\text { Treatment } \\
\text { status }\end{array}$} & \multicolumn{4}{|l|}{ Group } \\
\hline & \multicolumn{2}{|c|}{$\begin{array}{l}\text { H pylori eradicated } \\
(n=7)\end{array}$} & \multicolumn{2}{|c|}{$\begin{array}{l}\text { H pylori not eradicated } \\
(n=6)\end{array}$} \\
\hline & Total LI\% & Zone 2 LI\% & Total LI\% & Zone $2 \mathrm{LI} \%$ \\
\hline $\begin{array}{l}\text { Before } \\
\text { After }\end{array}$ & $\begin{array}{l}7.6(0.86) \\
4.5(0.53) \\
p=0.02\end{array}$ & $\begin{array}{l}19.5(2 \cdot 1) \\
11.5(1.48) \\
p=0.02\end{array}$ & $\begin{array}{l}6.5(0.81) \\
5.3(0.71) \\
p=0.03\end{array}$ & $\begin{array}{l}19.9(2.37) \\
13.0(1.96) \\
\mathrm{p}=0.09\end{array}$ \\
\hline
\end{tabular}

$\mathrm{LI}=$ labelling index. Analysis of paired data from subjects before and four weeks after eradication therapy confirms the reduction in cell proliferation whether $H$ pylori has been reduction in cell praticat or not.

\section{CELL PROLIFERATION AFTER ERADICATION}

TREATMENT (TABLES III-VI AND FIGURES 2-7)

Antral total and zone $2 \mathrm{LI} \%$ were reduced in patients four weeks after completing a course of anti-helicobacter therapy compared with untreated patients with $H$ pylori associated gastritis $(p=0.0001)$, whether the organism has been eradicated or not. This trend is confirmed by analysis of paired data from subjects before and after $H$ pylori eradication therapy. Twelve patients underwent further biopsy a mean of 12 (range 6-18) months after completion of eradication therapy. Total and zone $2 \mathrm{LI} \%$ in eight $H$ pylori negative subjects, that is, those treated successfully, were significantly lower $(p=0.024)$ than those present in four $H$ pylori positive patients. This trend is confirmed by analysis of paired data from subjects before and after $H$ pylori eradication therapy.

\section{Discussion}

In this study we used the technique of in vitro bromodeoxyuridine labelling to identify cells in
Figure 3: (A), (B) and, (C) Results at mean 12 (range. 6-18) months. Subjects who had not eradicated H pylori a mean of 12 months after completing a course of triple therapy have increased antral zone 2 labelling index (LI\%) compared with patients four weeks after completing triple therapy, regardless of outcome, and those tested 6-18 (mean 12) months after eradication of the organism. 
TABLE V Effect of time after eradication therapy

\begin{tabular}{|c|c|c|c|c|}
\hline & \multicolumn{4}{|l|}{ Group } \\
\hline & \multicolumn{2}{|c|}{4 Weeks after treatment } & \multicolumn{2}{|c|}{ 6-18 Months after treatment } \\
\hline & $\begin{array}{l}\text { H pylori eradicated } \\
(n=20)\end{array}$ & $\begin{array}{l}\text { H pylori not eradicated } \\
(n=14)\end{array}$ & $\begin{array}{l}\text { H pylori eradicated } \\
(n=8)\end{array}$ & $\begin{array}{l}\mathrm{H} \text { pylori not eradicated } \\
(n=4)\end{array}$ \\
\hline $\begin{array}{l}\text { Mean (SEM) age (y) } \\
\text { Mean (SEM) LI\%: }\end{array}$ & $45 \cdot 2(2 \cdot 65)$ & $46 \cdot 1(3 \cdot 02)$ & $42 \cdot 5(5 \cdot 14)$ & $41 \cdot 3(7 \cdot 04)$ \\
\hline $\begin{array}{l}\text { Zone } 1 \\
\text { Zone } 2 \\
\text { Zone } 3 \\
\text { Total LI\% }\end{array}$ & $\begin{array}{c}0.9(0.21) \\
12.0(0.96) \\
0.8(0.2) \\
4.5(0.3)\end{array}$ & $\begin{array}{r}1.42(0.3) \\
11.8(1.22) \\
1.0(0.26) \\
4.9(0.50)\end{array}$ & $\begin{array}{r}0.1(0.08) \\
11.5(0.98) \\
0.2(0.15) \\
3.7(0.33)\end{array}$ & $\begin{array}{c}0.3(0.09) \\
18 \cdot 7(1.29)^{\star} \\
0 \cdot 2(0.2) \\
6.4(0.40)^{\star}\end{array}$ \\
\hline
\end{tabular}

Subjects who had not eradicated $H$ pylori a mean of 12 months after completing a course of triple therapy have increased total antral and zone 2 labelling index (LI\%) compared with their values four weeks after completing triple therapy, regardless of outcome, and those tested 6-18 (mean 12) months after eradication of the organism $(p=0 \cdot 024)$.

the $\mathrm{S}$ phase of the cell cycle. ${ }^{8}{ }^{9}$ This method correlates well with the in vivo method ${ }^{1011}$ and was used in preference to the simpler technique of proliferating cell nuclear antigen (PCNA) immunostaining. PCNA is overexpressed in gastric mucosal biopsy specimens ${ }^{12} 13$ and is a poor marker of cell proliferation at this site. ${ }^{9}$

We have shown that gastric mucosal cell proliferation, as measured by the labelling index, is increased in $H$ pylori associated chronic gastritis but not in chronic gastritis where the organism is absent. This suggests that chronic inflammation alone is not associated with increased gastric epithelial cell turnover and that $H$ pylori infection is required. Cytokines, free oxygen radicals, and other factors released by the inflammatory response after infection with $H$ pylori ${ }^{14}{ }^{15}$ may interact with cells in the proliferative compartment to increase cell proliferation. The density of inflammatory cell infiltration in the region of the isthmus of the gastric glands is consistent with this explanation. Alternatively, the increased cell proliferation may be a direct compensatory response to accelerated cell loss, and be related to an increase in the activity of growth factors. Growth factor receptors are highly expressed in the proliferative zone. ${ }^{16}$

Previous studies have reported increased cell proliferation in gastric atrophy but not in superficial gastritis. ${ }^{17} 18$ These studies did not specifically address $H$ pylori status. Both $H$ pylori positive subjects and those negative for the organism histologically may have been included in the studies. The combination of the two groups may prevent any statistical difference being detected when compared with subjects with normal gastric mucosa.

TABLE VI Long term (mean 12 (range 6-18) months) effect of Helicobacter pylori eradication on antral cell proliferation

\begin{tabular}{|c|c|c|c|c|}
\hline \multirow{3}{*}{$\begin{array}{l}\text { Treatment } \\
\text { status }\end{array}$} & \multicolumn{4}{|l|}{ Group } \\
\hline & \multicolumn{2}{|c|}{$\begin{array}{l}\mathrm{H} \text { pylori eradicated } \\
(n=4)\end{array}$} & \multicolumn{2}{|c|}{$\begin{array}{l}\text { H pylori not eradicated } \\
(n=4)\end{array}$} \\
\hline & Total LI\% & Zone $2 L I \%$ & Total LI\% & Zone $2 \mathrm{LI} \%$ \\
\hline $\begin{array}{l}\text { Before } \\
\text { After }\end{array}$ & $\begin{array}{l}8.4(0.99) \\
3.4(0.41) \\
p=0.06\end{array}$ & $\begin{array}{c}22.8(2.5) \\
9.9(1.2) \\
\mathrm{p}=0.06\end{array}$ & $\begin{array}{l}7 \cdot 3(0.58) \\
6 \cdot 4(0.4) \\
p=0.5\end{array}$ & $\begin{array}{l}17 \cdot 4(1 \cdot 37) \\
18 \cdot 7(1 \cdot 29) \\
\mathrm{p}=0.8\end{array}$ \\
\hline
\end{tabular}

Analysis of paired data shows that total antral and zone 2 labelling indices $(\mathrm{LI} \%)$ are reduced towards normal a mean of 12 (range 6-18) months after eradication of $H$ pylori, but remain increased where infection with the organism persists.
We have shown similar increases in antral mucosal cell proliferation in ulcer and nonulcer patients. Non-ulcer associated gastritis usually affects both the antrum and corpus of the stomach (pangastritis) and is associated with a higher risk of gastric carcinoma than the predominantly antral, duodenal ulcer-associated gastritis. The difference in topographical distribution of non-ulcer associated gastritis is thought to account for the difference in cancer risk. ${ }^{1920}$ The histological and physiological changes that occur in pangastritis, namely atrophy and intestinal metaplasia in both antrum and corpus, lead to hypochlorhydria and proliferation of bacteria capable of nitrate reduction. This could result in production of nitrosocompounds which may be responsible for mutagenic events. The normal or increased acid levels in duodenal ulcer subjects would prevent this situation arising. The mucosal damage caused by $H$ pylori may allow nitrosocompounds and other mutagenic agents such as bile and free radicals increased access to proliferating gastric epithelial cells. ${ }^{21}$ Gastric juice vitamin C may play a role in the prevention of gastric cancer through its ability to scavenge oxygen free radicals and nitrite, a precursor of $\mathrm{N}$-nitrosocompounds. ${ }^{22} 23$ Vitamin C secretion is impaired in subjects with $H$ pylori associated gastritis, ${ }^{24} 25$ and eradication of the organism returns secretion to normal. ${ }^{26}$

We found that cell proliferation returned to normal four weeks after triple therapy, irrespective of the subject's $H$ pylori status. This may have been a non-specific effect of treatment. Bismuth has anti-inflammatory effects ${ }^{27}$ and may remain in the gastric mucosa for weeks after the completion of treatment. Because of this unexpected finding, patients were followed up with endoscopy and biopsy for a period ranging from six to 18 months after treatment. None of the patients had any other anti-helicobacter treatment in the interim. Those in whom $H$ pylori eradication had been successful continued to have a normal mucosal proliferation rate but in those in whom eradication had failed cell proliferation returned to its previously high level.

This is the first report of the long term effect of $H$ pylori eradication on gastric mucosal cell kinetics. Given that increased cell proliferation enhances the likelihood of genetic damage it seems reasonable to suggest that eradication of $H$ pylori may reduce the risk of gastric neoplasia. ${ }^{28}$ 
In conclusion, we have shown that gastric mucosal cell proliferation is increased in $H$ pylori associated gastritis and returns to normal after eradication therapy. This may have implications for gastric carcinogenesis and its prevention.

1 Morson BC. Intestinal metaplasia of the gastric mucosa. $\mathrm{Br}$ f Cancer 1955; 9: 365 .

2 Correa P. The gastric precancerous process. Cancer Surv 1983; 2: 437-50.

3 Nomura A, Stemmermann GN, Chyou P, Kato I, PerezPerez GI, Blaser MJ. Helicobacter pylori infection and gastric carcinoma among Japanese Americans in Hawaii. N Engl f Med 1991; 325 (16): 1132-6.

4 Forman D, Newell DG, Fullerton F, Yarnell JWG, Stacey AR, Wald N, et al. Association between infection with AR, Wald N, et al. Association between infection with Helicobacter pylori and risk of gastric cancer: evidence
from a prospective investigation. BMF 1991; 302: 1302-5.

5 Parsonnet J, Friedman GD, Vandersteen DP, Chang Y, Vogelman $\mathrm{JH}$, Orentreich $\mathrm{N}$, et al. Helicobacter pylor infection and the risk of gastric carcinoma. $N$ Engl $\mathscr{f} \mathrm{Med}$ 1991; 325: 1127-31

6 The Eurogast Study Group. An international association between Helicobacter pylori infection and gastric cancer. Lancet 1993; 341: 1359-62.

7 Medline A, Farber E. The multi-step theory of neoplasia. In: Anthony PP, Sweeney RNM, eds. Recent advances in histopathology. No 11. Edinburgh: Churchill Livingstone, 1981: 19-34.

8 Freling RI. Culture of animal cells. A manual of basic technique. 2nd ed. New York: Alan R Liss Inc, 241-4.

9 Lynch DAF, Clarke AMT, Jackson P, Axon ATR, Dixon MF, Quirke P. Comparison of labelling by bromodeoxyuridine, MIB-1 and proliferating cell nuclear antigen in gastric mucosal biopsies. $\mathcal{F}$ Clin Pathol 1994; 47: 122-5.

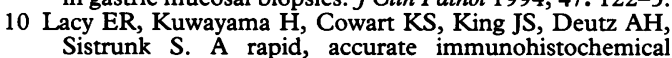
method to label proliferating cells in the digestive tract. A comparison with tritiated thymidine. Gastroenterology 1991; 100: 259-62.

11 Ohyama S, Yonemura Y, Miyazaki I. Proliferative activity and malignancy in human gastric cancers: significance of and malignancy in human gastric cancers: significance of the proliferation
1992; 69: 314-21.

12 Hall PA, Hart I, Goodlad R, Coates PJ, Lane DP. Expression of proliferating cell nuclear antigen in noncycling cells. F Pathol 1992; 168: 97A

13 Wisman JH, Van Dierendonck JH, Keijzer R, Van de Velde $\mathrm{CJH}$, Cornelisse CJ. Immunoreactivity of proliferating cell nuclear antigen compared with bromodeoxyuridine incorporation in normal and neoplastic rat tissue. $f$ Patho 1992; 168: 75-83.

14 Emery P, Salmon M. Systemic mediators of inflammation. Br f Hosp Med 1991; 45: 164-8.

15 Lunec J. Free radicals: their involvement in disease processes. Ann Clin Biochem 1990; 27: 173-82.

16 Jankowski J, Al-Rawi HJ, Johnston DA, Hopwood D, Filipe MI, Coghill G, et al. Growth regulatory peptides in gastric mucosa. Clin Sci 1992; 82: 581-7.

17 Hansen OH, Johansen AA, Larsen JK, Svendson LB. Cell proliferation in normal and diseased gastric mucosa. Acta Pathologica et Microbiologica Scandinavica 1979; 87: 217-22.

18 Yong-ling $\mathrm{X}$, Zhi-tian $\mathrm{Z}$. Cell proliferation kinetics in chronic gastritis and gastric cancer. Chin Med $\mathcal{f}$ (Engl) 1984; 97: 526-32.

19 Dixon MF. Helicobacter pylori and peptic ulceration: Histopathological aspects. Fournal of Gastroenterology $\mathcal{E}$ Hepatology 1991; 6: 125-30.

20 Axon ATR, Lynch DAF. Helicobacter pylori, gastric physiology and cancer. European fournal of Gastroenterology $\mathcal{E}$ Hepatology 1993; 5 (suppl 1): S100-13.

21 Ames BN, Gold LS. Too many rodent carcinogens: mitogenesis increases mutagenesis. Science 1990; 249: 970-1.

22 Mirvish SS, Wallcave L, Eagen M, Shubik P. Ascorbatenitrite reaction: possible means of blocking the formation of carcinogenic N-nitrosocompounds. Science 1992; 177: 65-8.

23 Mackerness CW, Leach SA, Thompson MH, Hill MJ. The inhibition of bacterially mediated-nitrosation by vitamin $\mathrm{C}$ : relevance to the inhibition of endogenous $\mathrm{N}$-nitrosation in the achlorhydric stomach. Carcinogenesis 1989; 10: tion in the

24 Sobala GM, Schorah CJ, Sanderson M, Dixon MF, Tompkins DS, Godwin P, et al. Ascorbic acid in the human stomach. Gastroenterology 1989; 97: 357-63.

25 Rathbone BJ, Johnson AW, Wyatt JI, Kelleher J, Heatley RV, Losowsky MS. Ascorbic acid: a factor concentrated in human gastric juice. Clin Sci 1989; 76: 237-41.

26 Sobala GM, Schorah CJ, Shires S, Lynch DAF, Gallacher B, Dixon MF, et al. Effect of eradication of Helicobacter pylori on gastric juice ascorbic acid concentrations. Gut 1993; 34: 1038-41.

27 Lanza FL, Skoglund ML, Rack MF, Yardley JH. The effect of bismuth subsalicylate on the histologic gastritis effect of bismuth subsalicylate on the histologic gastritis
seen with Campylobacter pylori: a placebo-controlled, seen with Campylobacter pylori: a placebo-controlled, randomized

28 Rauws EAJ, Langenburg W, Houthoff HJ, Zanen HC, Tytgat GNJ. Campylobacter pyloridis associated chronic antral gastritis. A prospective study of its prevalence and the effects of antibacterial and antiulcer treatment. Gastroenterology 1988; 94: 33-40. 